\title{
Changes in protein distribution in normal and protein-deficient rats during an acute-phase 'injury' response
}

\author{
BY G. JENNINGS AND M. ELIA \\ Dunn Nutrition Unit, Downhams Lane, Milton Road, Cambridge CB4 $4 X J$
}

(Received 5 June 1995 - Revised 3 November 1995 - Accepted 10 November 1995)

\begin{abstract}
The present study investigated the effect of the acute-phase 'injury' response, induced by subcutaneous injection of turpentine, on the hydration and protein content of organs and tissues of normally nourished rats receiving a diet containing $200 \mathrm{~g}$ protein $/ \mathrm{kg}$, and of protein-malnourished rats receiving a diet containing $30 \mathrm{~g}$ protein $/ \mathrm{kg}$. The measurements were carried out $48 \mathrm{~h}$ after turpentine injection, and were compared with both saline-injected animals, and pair-fed control animals. Circulating $\alpha_{2}$-macroglobulin was also measured as an index of the acute-phase-protein response. In normally nourished rats turpentine injection caused a significant increase in the mean masses of the liver, kidney and lung (7-35\% compared with saline-injected animals, and $20-44 \%$ compared with pair-fed controls), and a small reduction in the mass of extra-abdominal and extrathoracic tissues ('carcass'). In general the protein content of tissues changed in a similar way (for liver, kidney and lung a 16-33\% increase compared with saline-injected animals, and 32-49\% compared with pair-fed controls). Protein deficiency produced a significant attenuation in the response to turpentine. The change in the mass and protein content of several tissues was reduced (for lung, liver and kidney, the increase in protein content was only 5-15\%), and the effects on anorexia ( $1 \mathrm{v} .41 \%$ reduction in food intake) and the $\alpha_{2}$-macroglobulin response (1.28 v. $4.28 \mathrm{~g} / \mathrm{l}$; $\boldsymbol{P}<0.001)$ were also reduced. It is concluded that the injury response spares most central thoracic and abdominal organs, but this effect as well as the anorexia and acute-phase-protein response to injury are attenuated by protein deficiency.
\end{abstract}

Protein deficiency: Acute-phase response: Injury

Disease and injury cause catabolism or loss of body protein (negative $\mathbf{N}$ balance), but tissues do not lose protein equally. For example, in a turpentine model of injury, muscle loses protein because of a decrease in muscle protein synthesis, but liver may gain protein because of an increase in protein synthesis (Wusteman et al. 1990). Other studies with endotoxin, scalds, or infusion of live Escherichia coli bacteria in rats also suggest that muscle is preferentially lost, and liver preferentially preserved (Thelfall et al. 1979; Pedersen et al. 1987; Ash \& Griffin, 1989; Fong et al. 1991; Wusteman \& Elia, 1991; Wusteman et al. 1994, 1995a). The lung may also be involved in the complex changes in protein distribution after injury, since cytokines such as tumour necrosis factor (TNF), which increase after injury, produce an increase in the size and protein content of the lung (Ferrari-Baliviera et al. 1989; Grimble et al. 1992). Other workers (Stein et al. 1977) have shown that there is an increase in protein synthesis in the lung after fracture of the femur in the rat.

However, information about changes in protein distribution during the acute-phase response is incomplete for at least three reasons. First, some studies have failed to include a pair-fed control group, which means that they are unable to distinguish between the effects due directly to injury and those due to reduced feed intake (Carter et al. 1988; Jepson et al. 1988; Tran et al. 1991). Furthermore some studies have exaggerated the dietary effect 
by starving the animals (Ardawi, 1992). Second, the information from some studies is incomplete either because of the limited number of tissues examined (sometimes only one) (Thelfall et al. 1979; Pedersen et al. 1987; Jones et al. 1990; Fong et al. 1991; Tran et al. 1991; Wusteman et al. 1995 b) or two (Wusteman et al. 1990), or because changes in the weight of tissues or organs have been given without information about their protein content. It is possible that changes in the wet weight of tissues after injury, which may be influenced by altered dietary intake (Addis et al. 1936; Garlick et al. 1975), do not reflect changes in their water content. For example, an increase in the protein fraction of the liver has been reported in the starving rat (Garlick et al. 1975), whereas an increase in the hydration fraction of the liver has been reported in the septicaemic rat (Pederson et al. 1987). Third, virtually all the information about protein distribution after injury has been obtained in normal animals fed on a normal diet. Some studies have assessed the acutephase effects of endogenous pyrogen (Bell \& Hoffman-Goetz, 1983) or cytokines such as interleukin-1 (Drabik et al. 1987) in both normal and protein-deficient animals, but have not assessed the effect on tissue protein distribution. Important information about the effects of TNF in protein-deficient animals have been provided by Hunter \& Grimble (1994) and Grimble et al. (1992). However, this information is limited either because measurements were made in only two tissues (lung and liver, Hunter \& Grimble, 1994) or because no measurements were made of the protein and water content of tissues (Grimble et al. 1992). In addition the changes induced by single cytokines may be quite different from 'injury' responses. For example, in the study of Grimble et al. (1992) TNF injections produced only a 3-10-fold increase in the concentration of the acute-phase protein $\alpha_{2}$-macroglobulin response, compared with a much greater increment (by one order of magnitude) produced in the turpentine model of injury (Jennings \& Elia, 1992).

The confounding effects of malnutrition induced by low-protein diets do not appear to have been examined. Protein deficiency attenuates several of the acute-phase changes after injury (aseptic abscesses induced by turpentine), including the acute-phase-protein response ( $\alpha_{2}$-macroglobulin response) (Jennings \& Elia, 1991, 1992, 1994; Jennings et al. 1992a, b). Whether changes in protein distribution are also attenuated in this model of injury is unknown.

The purpose of the present study was to undertake a detailed investigation of the effects of injury on the changes in tissue protein distribution in various tissues, to distinguish between the direct effect due to injury and that of anorexia, and to test the hypothesis that protein deficiency not only attenuates the acute-phase protein response but also anorexia and the changes in protein distribution.

\section{METHODS}

Thirty-six male rats from our colony of hooded animals were weaned at $21 \mathrm{~d}$ of age and fed ad libitum on a purified diet containing $200 \mathrm{~g}$ protein $/ \mathrm{kg}$ (Lunn et al. 1976). The animals were bred in one environment and raised in another environment whilst our animal housing facilities were being refurbished. At $28 \mathrm{~d}$ of age the rats were divided into two equal groups (eighteen rats per group). Group 1 was given the $200 \mathrm{~g}$ protein $/ \mathrm{kg}$ diet, whereas group 2 was given a low-protein diet $(30 \mathrm{~g}$ protein $/ \mathrm{kg}$, in which most of the protein was replaced with sugar and starch in equal proportions so that it was isoenergetic with the $200 \mathrm{~g}$ protein $/ \mathrm{kg}$ diet $(16.7 \mathrm{MJ} / \mathrm{kg})$ ). The intake of a $30 \mathrm{~g}$ protein $/ \mathrm{kg}$ diet ad libitum results in a near normal intake of energy per $100 \mathrm{~g}$ body weight; in young rats this will maintain body weight but will prevent growth (Jennings \& Elia, 1991).

At $42 \mathrm{~d}$ of age six rats from each dietary group were injected subcutaneously on the dorsum with turpentine at a dose of $5 \mathrm{ml} / \mathrm{kg}$ body weight. Since this results in a reduction 
in feed intake, six rats from each dietary group were pair-fed to the mean daily intake of the corresponding turpentine-injected rats. The final six rats in each dietary group were injected with saline ( $150 \mathrm{mM}-\mathrm{NaCl} ; 5 \mathrm{ml} / \mathrm{kg}$ body weight) and used as controls.

At $44 \mathrm{~d}$ of age (i.e. $2 \mathrm{~d}$ after injection or $2 \mathrm{~d}$ after pair-feeding) the rats were killed by cervical dislocation and blood (3-5 ml) was collected from the heart and placed into $5 \mathrm{ml}$ tubes containing $160 \mathrm{IU}$ heparin. Plasma was separated by centrifugation at $4^{\circ}$, and stored at $-20^{\circ}$ until analysis. The heart, lungs, kidney, liver and gastrocnemius muscle were removed, blotted on tissue paper and weighed. The small and large intestines were removed, rinsed in saline, blotted on tissue paper and weighed. All tissue samples were then kept at $-20^{\circ}$ until analysis.

Plasma was analysed for $\alpha_{2}$-macroglobulin by single radial diffusion (Jennings \& Elia, 1992). Tissue water content was measured by freeze-drying to a constant weight, and tissue $\mathrm{N}$ was determined in duplicate using samples of approximately $5 \mathrm{mg}$ powdered freeze-dried tissue. The measurements were carried out using a Carlo Erba automatic $\mathbf{N}$ analyser (model 1500 , Fisons Instruments, Crawley, Sussex). The protein content of a tissue was calculated by multiplying its $\mathrm{N}$ content by $6 \cdot 25$.

Body weights and feed intake were measured daily throughout the experiment.

\section{RESULTS}

Body weights and feed intake

From $28-42 \mathrm{~d}$ of age the rats on the $200 \mathrm{~g}$ protein $/ \mathrm{kg}$ diet consumed approximately $140 \mathrm{~g} / \mathrm{d}$ per $\mathrm{kg}$ body weight. They increased their body weight at a rate of about $7 \mathrm{~g} / \mathrm{d}$. The rats on the protein-deficient diet, as expected from previous work (Jennings \& Elia, 1991), consumed a similar amount of feed on a weight basis, and did not increase their body weight. The feed intake of the saline-injected rats in both dietary groups was similar in the pre- and post-injection periods (Fig. 1). In contrast the feed intake of the turpentineinjected rats on the $200 \mathrm{~g}$ protein $/ \mathrm{kg}$ diet was reduced by $29 \%$ on the first day and $54 \%$ on the second day, resulting in an overall reduction of $41 \%$ during the $48 \mathrm{~h}$ following turpentine injection. The rats on the low-protein diet also consumed less feed $(22 \%)$ in the first $24 \mathrm{~h}$ after turpentine injection (Fig. 1), but more on the subsequent day (23\%), so that in the entire $48 \mathrm{~h}$ period there was essentially no overall change in feed intake.

Body weight in the rats receiving the $200 \mathrm{~g}$ protein $/ \mathrm{kg}$ diet was reduced by turpentine injection, but not saline injection. The loss of body weight, in the turpentine-injected rats was reproduced by pair-feeding (Fig. 2). The body weight of rats receiving the low-protein diet was not significantly affected by turpentine or saline injection, nor was it affected by pair-feeding (Fig. 2). The saline-injected rats on the low-protein diet maintained their preinjection weight as did the pair-fed and turpentine-treated rats in this dietary group.

\section{Organ size and composition}

To minimize differences due to body size, the weights of tissues are expressed as a proportion of body weight (Table 1 ). In the rats on the $200 \mathrm{~g}$ protein $/ \mathrm{kg}$ diet the lower feed intake of the pair-fed rats caused a significant reduction in relative size of some tissues (liver, small intestine and large intestine) compared with the rats fed ad libitum (Table 1). To account for the effects due to reduced feed intake, the turpentine-treated rats within each group were compared with the pair-fed rats. Turpentine caused an increase in the weight of liver $(P<0.001)$, kidney $(P<0.01)$, lungs $(P<0.05)$ and small intestine $(P<0.01)$ of rats fed on the $200 \mathrm{~g}$ protein $/ \mathrm{kg}$ diet. Similar trends were found in the protein- 


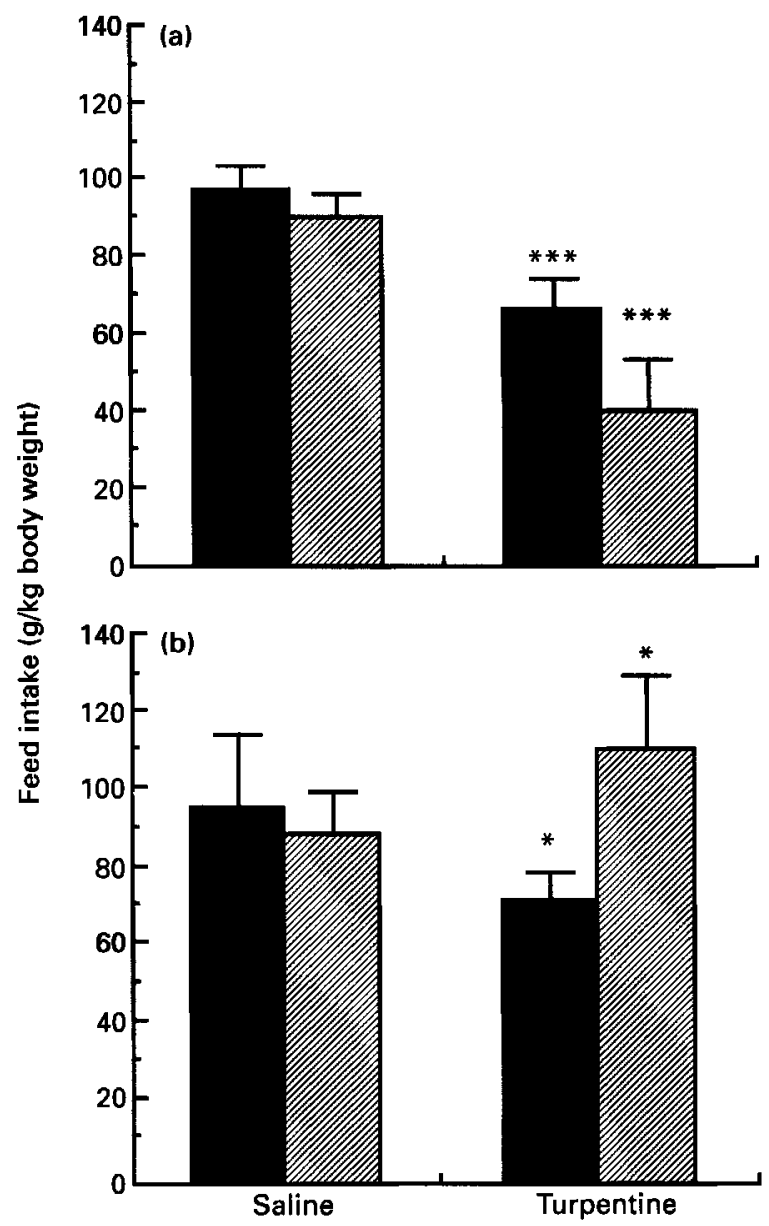

Fig. 1. The effect of turpentine and saline injections on feed intake of rats fed on diets containing (a) $200 \mathrm{~g}$ protein $/ \mathrm{kg}$ or (b) $30 \mathrm{~g}$ protein $/ \mathrm{kg}$ on day $1(\square)$ and day $2(\mathbb{Q})$. Mean feed intake values were significantly different from corresponding saline controls: ${ }^{*} P<0.05 ;{ }^{* *} P<0.001$.

deficient rats, and although the changes were attenuated, turpentine still caused an increase in the weight of liver $(P<0.001)$, kidney $(P<0.01)$ and heart $(P<0.05)$. The increase in liver size due to turpentine injection of the rats on the $200 \mathrm{~g}$ protein $/ \mathrm{kg}$ diet $(44 \%)$ was significantly greater $(P<0.001)$ than that of the rats on the protein-deficient diet $(24 \%)$.

Turpentine injection in normally nourished animals did not significantly change the hydration fraction of tissues, but pair-feeding caused an independent increase (Table 2). As a result the heart, kidneys and large gut of the animals injected with turpentine had a lower hydration fraction than the same tissues from pair-fed animals (Table 2). The opposite trends were observed in the protein-deficient animals because turpentine administration increased the hydration of several tissues, but pair-feeding did not. The only tissue to show a significant reduction in hydration after turpentine was muscle (Table 2).

Turpentine injection in normally nourished animals significantly increased the protein content of several abdominal and thoracic organs (30-50\%), whilst pair-feeding decreased it (Table 3). In protein-malnourished animals turpentine produced smaller increments in protein content of organs (significant only for liver $(P<0.01)$ and kidney $(P<0.05))$. The 


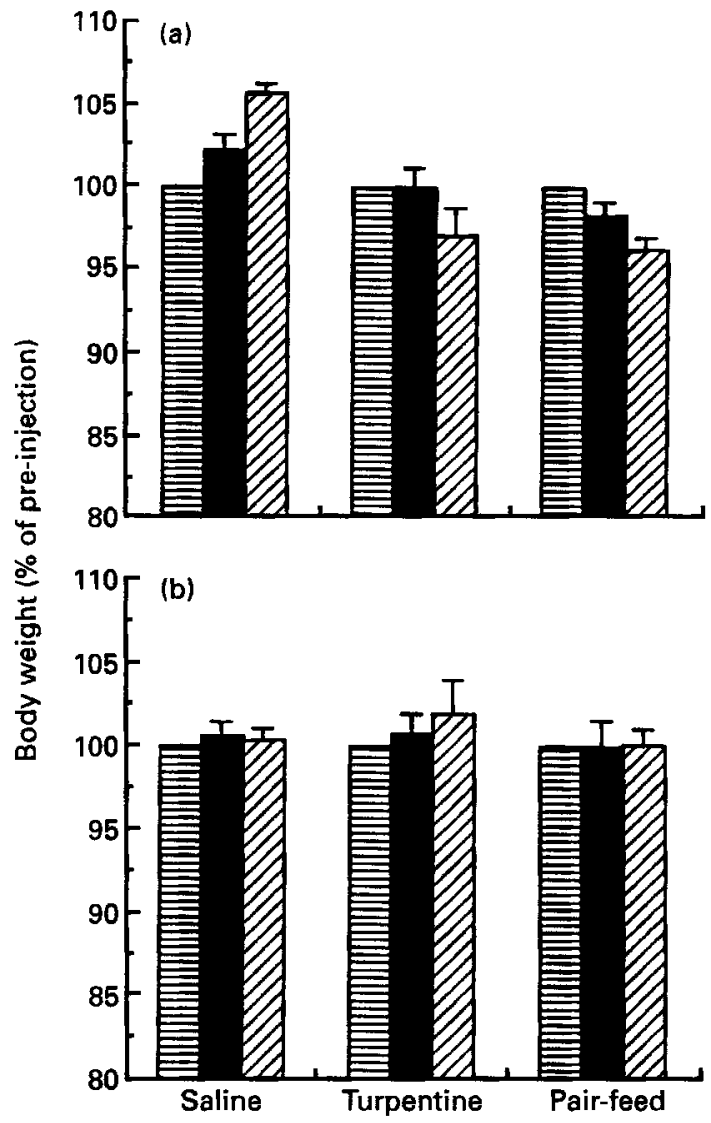

Fig. 2. The effect of turpentine injection, saline injection and pair-feeding on body weight of rats fed on diets containing (a) $200 \mathrm{~g}$ protein $/ \mathrm{kg}$ or (b) $30 \mathrm{~g}$ protein $/ \mathrm{kg}$ on day 1 ( $\square$ ) and day 2 ( $\square$ ). Weights are expressed as a percentage of the pre-injection weight (国).

increments in the rats on the adequate-protein diet were significantly greater than those found in the protein-deficient rats e.g. for liver $(31.9 v .12 .8 \% ; P<0.001)$, lung (48.9v. $17.9 \% ; P<0.05)$ and kidney $(32.8$ v. $7.1 \% ; P<0.01)$. Turpentine injection decreased the protein content of the muscle and 'carcass' of both the normally nourished and proteindeficient animals, but the change in the protein content of the 'carcass' of the normally nourished animals did not reach statistical significance.

\section{$\alpha_{2}-$ Macroglobulin response}

As in our previous studies (Jennings \& Elia, 1991, 1992, 1994; Jennings et al. 1992a, b), turpentine injection increased the circulating $\alpha_{2}$-macroglobulin concentration to a lesser extent in the protein-deficient animals than in the normally nourished animals (1.28 (SD 0.28 ) v. 4.85 (SD 0.55) g/l) (Table 4). However, the $\alpha_{2}$-macroglobulin response in both normal and protein-deficient animals was less than reported previously by our group (Jennings \& Elia, 1991, 1992; Jennings et al. 1991, 1992a, b), possibly because the animals were bred in one environment and raised in another environment whilst there was refurbishment of our own facilities, and possibly because the concentration of $\alpha_{2^{-}}$ macroglobulin is variable at $2 \mathrm{~d}$ (Jennings et al. 1992b). The protein-deficient diet produced 
Table 1. Relative tissue weights ( $\mathrm{g} / \mathrm{kg}$ body weight) in rats injected with turpentine or saline and pair-fed controls, fed on diets containing 200 or $30 \mathrm{~g}$ protein $/ \mathrm{kg} \ddagger$

(Mean values and standard deviations for six rats per group)

\begin{tabular}{|c|c|c|c|c|c|c|}
\hline & \multicolumn{2}{|c|}{ Saline } & \multicolumn{2}{|c|}{ Pair-fed } & \multicolumn{2}{|c|}{ Turpentine } \\
\hline & Mean & $\mathrm{SD}$ & Mean & SD & Mean & SD \\
\hline \multicolumn{7}{|l|}{$200 \mathrm{~g}$ protein $/ \mathrm{kg}$} \\
\hline Liver & $46 \cdot 7$ & $1 \cdot 1$ & $34 \cdot 7+t+$ & $1 \cdot 1$ & $50 \cdot 0 * * *++\dagger$ & $1 \cdot 1$ \\
\hline Heart & $4 \cdot 0$ & $1 \cdot 3$ & $4 \cdot 2$ & $0 \cdot 3$ & $4 \cdot 5$ & 0.6 \\
\hline Kidney & $8 \cdot 8$ & 0.5 & $8 \cdot \overline{5}$ & 0.4 & $10 \cdot 2^{* * *+\dagger \dagger}$ & 0.5 \\
\hline Lung & $7 \cdot 4$ & $1 \cdot 3$ & $7 \cdot 5$ & 0.1 & $10 \cdot 0 * \dagger$ & $2 \cdot 6$ \\
\hline Small intestine & $18 \cdot 4$ & $1 \cdot 6$ & $15 \cdot 3 \dagger t$ & 0.7 & $17 \cdot 5^{* *}$ & $1 \cdot 1$ \\
\hline Large intestine & $5 \cdot 7$ & 0.5 & $3.9+\dagger \dagger$ & 0.4 & $4 \cdot 0+1 \dagger$ & $0 \cdot 3$ \\
\hline Muscle & $7 \cdot 1$ & $0 \cdot 2$ & $7 \cdot 2$ & 0.4 & 6.9 & 0.5 \\
\hline Carcass & $889 \cdot 5$ & $3 \cdot 5$ & $892 \cdot 2$ & $4 \cdot 3$ & $870 \cdot 5^{* * *+1}$ & $5 \cdot 6$ \\
\hline \multicolumn{7}{|l|}{$30 \mathrm{~g}$ protein $/ \mathrm{kg}$} \\
\hline Liver & $39 \cdot 3$ & $1 \cdot 3$ & $38 \cdot 2$ & $2 \cdot 1$ & $47 \cdot 2 * * *+\dagger \dagger$ & $1 \cdot 7$ \\
\hline Heart & $4 \cdot 5$ & 0.3 & $4 \cdot \overline{2}$ & 0.2 & $4 \cdot 7^{*}$ & 0.4 \\
\hline Kidney & $9 \cdot 1$ & 0.3 & $8 \cdot 4$ & 0.8 & $10 \cdot 0^{* *+\dagger}$ & 0.6 \\
\hline Lung & 8.0 & 1.6 & $7 \cdot 6$ & $1 \cdot 0$ & $9 \cdot 7$ & 3.4 \\
\hline Small intestine & $17 \cdot 9$ & $2 \cdot 7$ & $16 \cdot 2$ & $1 \cdot 2$ & $16 \cdot 8$ & 1.6 \\
\hline Large intestine & 5.9 & 0.2 & $5 \cdot 6$ & $1 \cdot 0$ & $5 \cdot 1+\dagger$ & 3.8 \\
\hline Muscle & $7 \cdot 3$ & 0.7 & $6 \cdot 9$ & 0.5 & 6.7 & 0.6 \\
\hline Carcass & $890 \cdot 7$ & $6 \cdot 8$ & 900.3 & $3 \cdot 2$ & $886 \cdot 4^{* * *}$ & $4 \cdot 9$ \\
\hline
\end{tabular}

Mean values were significantly different from those for the pair-fed group: ${ }^{*} P<0.05,{ }^{* *} P<0.01$, $* * * P<0.001$.

Mean values were significantly different from those for the saline group: $\uparrow P<0.05$, $\uparrow \dagger P<0.01, \dagger \dagger \dagger P<0.001$.

$\$$ For details of diets and procedures, see pp. 124-125.

a small increase in the basal (pre-turpentine) concentration of $\alpha_{2}$-macroglobulin and pairfeeding had no additional affect.

\section{DISCUSSION}

This study provides comprehensive information about the changes in protein distribution produced by turpentine administration, and distinguishes between the effects due to injury and anorexia. It also demonstrates how protein deficiency modifies these responses.

Although 'injury' produces muscle wasting, some central tissues are preferentially preserved (the present study and Thelfall et al. 1979; Ash \& Griffin, 1989; Ferrari-Baliviera et al. 1989; Grimble et al. 1992; Hunter \& Grimble, 1994; Besler \& Grimble, 1995). The present study shows that reduced feed intake in normally nourished animals produces a reduction in protein content of most tissues, but turpentine administration results in preferential preservation of the protein content of most central organs (compared with pair-fed animals (Table 3)). Indeed administration of turpentine to normally nourished rats not only resulted in an increase in the protein content of the lung and liver relative to pairfed animals ( $33 \%$ and $44 \%$ respectively) but also relative to control animals injected with saline (35\% and $7 \%$ respectively). These trends, which are also observed with respect to the protein content of tissues, seem to occur at the expense of the remaining tissues (carcass) especially muscle, but the contribution of skin is probably also important (Wusteman et al. 1994). The increase in the size of organs such as the liver is not due to an acute inflammatory reaction within the tissue because histology is normal (Wusteman et al. 1990; 
Table 2. Percentage hydration of the tissues of rats injected with turpentine or saline and pair-fed controls, fed on diets containing 200 or $30 \mathrm{~g}$ protein $/ \mathrm{kg} \ddagger$

(Mean values and standard deviations for six rats per group)

\begin{tabular}{|c|c|c|c|c|c|c|}
\hline & \multicolumn{2}{|c|}{ Saline } & \multicolumn{2}{|c|}{ Pair-fed } & \multicolumn{2}{|c|}{ Turpentine } \\
\hline & Mean & SD & Mean & $\mathrm{SD}$ & Mean & SD \\
\hline \multicolumn{7}{|l|}{$200 \mathrm{~g}$ protein $/ \mathrm{kg}$} \\
\hline Liver & $70 \cdot 32$ & 0.51 & $70 \cdot 41$ & 0.55 & $70 \cdot 57$ & 0.77 \\
\hline Heart & 80.95 & 2.07 & $82 \cdot 48$ & 0.75 & $79 \cdot 67^{* * *}$ & $1 \cdot 10$ \\
\hline Kidney & 77.6 & 1.44 & $79 \cdot 42 \dagger$ & $1 \cdot 16$ & $77.05^{* *}$ & 1.29 \\
\hline Lung & $82 \cdot 16$ & 1.89 & $84 \cdot 45^{\dagger}$ & 1.27 & 82.85 & 2.44 \\
\hline Large intestine & 76.09 & 1.99 & $82 \cdot 19+t \dagger$ & 1.74 & $77 \cdot 32^{*}$ & 5.94 \\
\hline Small intestine & $72 \cdot 15$ & 2.92 & 67.81 & $4 \cdot 12$ & $69 \cdot 36$ & 1.89 \\
\hline Muscle & $76 \cdot 44$ & 1.02 & 77.35 & 0.85 & $76 \cdot 41$ & 0.93 \\
\hline Carcass & 63.86 & 1.61 & 61.67 & 1.67 & $63 \cdot 56$ & 1.92 \\
\hline \multicolumn{7}{|l|}{$30 \mathrm{~g}$ protein $/ \mathrm{kg}$} \\
\hline Liver & $69 \cdot 93$ & 0.66 & $69 \cdot 03$ & 0.58 & $70 \cdot 73^{* *}$ & $1 \cdot 10$ \\
\hline Heart & 73.04 & 1.47 & $76 \cdot 18+\dagger$ & 1.08 & $77 \cdot 55^{*+\dagger+\dagger}$ & 0.93 \\
\hline Kidney & $75 \cdot 43$ & 0.74 & 74.00 & 1.47 & $76-50^{* *}$ & 1.03 \\
\hline Lung & 74.93 & $4 \cdot 24$ & $78 \cdot 68$ & 1.79 & $80 \cdot 41+\dagger$ & $2 \cdot 30$ \\
\hline Large intestine & $72 \cdot 08$ & 1.97 & $73 \cdot 00$ & 4.43 & $70 \cdot 28$ & 3.93 \\
\hline Small intestine & 72.04 & 0.84 & 72.09 & $1 \cdot 15$ & $73-08 \dagger$ & 0.53 \\
\hline Muscle & $70 \cdot 11$ & 1.39 & $75 \cdot 26+1 \dagger$ & 0.96 & $73 \cdot 52^{* *}+\dagger \dagger$ & 0.69 \\
\hline Carcass & 65.98 & 0.77 & $68.65+4 \dagger$ & $1 \cdot 15$ & $68 \cdot 57 * *++4$ & 1.20 \\
\hline
\end{tabular}

Mean values were significantly different from those of the pair-fed group: ${ }^{*} P<0.05,{ }^{* *} P<0.01,{ }^{* * *} P<0.001$. Mean values were significantly different from those of the saline group: $\uparrow P<0.05, \uparrow \dagger P<0.01, \dagger \dagger \uparrow P<0.001$ $\ddagger$ For details of diets and procedures, see pp. 124-125.

Jennings et al. 1992b). The reason for the 'preferential' preservation of central organs, particularly the liver and lung, is not clear but these tissues are major components of the reticuloendothelial system which frequently increases its activity after injury. The activity and energy cost of metabolic processes such as gluconeogenesis and the overall hepatic protein synthetic rate (Wusteman \& Elia, 1990), including acute-phase-protein synthesis, are also increased after injury. In addition, the energy cost of maintaining a larger hepatic cell mass (e.g. $\mathrm{Na}$ pump activity and protein turnover) will contribute to the energy expenditure of splanchic tissues, but an increase in metabolic rate per gram of tissue is also possible (Elia, 1991). In normally nourished animals injected with turpentine the loss of large intestine appears to be due to the reduced feed intake, rather than to the systemic effect of injury. However the small intestine of normally nourished animals injected with turpentine shows no significant change compared with that of the saline-injected animals. The present study has not distinguished between mucosal and non-mucosal effects, but a previous study investigating the effects of single (Wusteman et al. 1995b) or repeated injections of turpentine (Wusteman et al. 1994) on the small-intestinal mucosa concluded that there was substantial loss of mucosal mass, which was reproduced by pair-feeding.

The present study also demonstrates that changes in organ size do not necessarily reflect the change in tissue composition after injury. Reduced feed intake in normally nourished animals produced an increase in the hydration fraction of several tissues, whilst the same dietary restriction in animals injected with turpentine produced no such effect. In contrast, turpentine injection in protein-malnourished animals increased the hydration fraction of some tissues but pair-feeding did not. Therefore it is possible for some tissues to show 
Table 3. Tissue protein content $(\mathrm{g} / \mathrm{kg}$ body weight) in rats injected with turpentine or saline and pair-fed controls, fed on diets containing 200 or $30 \mathrm{~g}$ protein $/ \mathrm{kg} \ddagger$

(Mean values and standard deviations for six rats per group)

\begin{tabular}{|c|c|c|c|c|c|c|}
\hline & \multicolumn{2}{|c|}{ Saline } & \multicolumn{2}{|c|}{ Pair-fed } & \multicolumn{2}{|c|}{ Turpentine } \\
\hline & Mean & SD & Mean & SD & Mean & SD \\
\hline \multicolumn{7}{|l|}{$200 \mathrm{~g}$ protein $/ \mathrm{kg}$} \\
\hline Liver & $8 \cdot 82$ & 0.66 & $7 \cdot 8+4$ & $0 \cdot 34$ & $10 \cdot 29 * * *+1+\dagger$ & $0 \cdot 37$ \\
\hline Heart & 0.59 & 0.10 & 0.56 & 0.04 & $0.73^{*}$ & 0.15 \\
\hline Kidney & $1 \cdot 38$ & $0 \cdot 16$ & $1 \cdot 28$ & $0 \cdot 12$ & $1 \cdot 70^{* * * *+1}$ & 0.09 \\
\hline Lung & 1.01 & 0.29 & 0.90 & 0.14 & $1 \cdot 34^{*}$ & $0 \cdot 34$ \\
\hline Large intestine & 0.89 & 0.08 & $0.49+\dagger \dagger$ & 0.07 & $0.56+\dagger \dagger$ & $0 \cdot 16$ \\
\hline Small intestine & 3.09 & 0.44 & $2 \cdot 71$ & 0.16 & 2.85 & 0.33 \\
\hline Muscle & $1 \cdot 24$ & 0.06 & $1 \cdot 19$ & 0.07 & $1 \cdot 16 \dagger$ & $0 \cdot 10$ \\
\hline Carcass & $204 \cdot 1$ & $17 \cdot 2$ & 189.8 & $2 \cdot 2$ & 189.9 & $7 \cdot 7$ \\
\hline \multicolumn{7}{|l|}{$30 \mathrm{~g}$ protein $/ \mathrm{kg}$} \\
\hline Liver & $7 \cdot 06$ & 0.41 & $7 \cdot 17$ & $0 \cdot 18$ & $8.09 * *+\dagger$ & 0.50 \\
\hline Heart & 0.89 & 0.09 & 0.82 & 0.04 & 0.86 & 0.06 \\
\hline Kidney & 1.66 & 0.07 & 1.68 & 0.07 & $1.80 * \dagger$ & $0 \cdot 10$ \\
\hline Lung & $1 \cdot 41$ & $0 \cdot 21$ & $1 \cdot 23$ & $0 \cdot 10$ & 1.45 & 0.44 \\
\hline Large intestine & 0.99 & 0.08 & 1.01 & 0.11 & 0.98 & $0 \cdot 10$ \\
\hline Small intestine & $3 \cdot 55$ & $0 \cdot 36$ & $3 \cdot 21$ & $0 \cdot 35$ & $3 \cdot 41$ & 0.51 \\
\hline Muscle & 1.43 & 0.12 & 1.35 & 0.13 & $1 \cdot 19 *+\dagger$ & 0.09 \\
\hline Carcass & $206-0$ & 3.9 & $187 \cdot 7++\dagger$ & $8 \cdot 5$ & $182 \cdot 6+t \dagger$ & $8 \cdot 4$ \\
\hline
\end{tabular}

Mean values were significantly different from those of the pair-fed group: $* P<0.05, * * P<0.01, * * * P<0.001$, Mean values were significantly different from those for the saline group: $\dagger P<0.05, \uparrow \dagger P<0.01, \uparrow \dagger \uparrow P<0.001$. $\ddagger$ For details of diets and procedures, see pp. 124-125.

Table 4. Plasma $\alpha_{2}$-macroglobulin concentrations $(\mathrm{g} / \mathrm{l})$ in rats injected with turpentine or saline and pair-fed controls, fed on diets containing 200 or $30 \mathrm{~g}$ protein $/ \mathrm{kg} \dagger$

(Mean values and standard deviations for six rats per group)

\begin{tabular}{|c|c|c|c|c|}
\hline \multirow[t]{2}{*}{ Diet... } & \multicolumn{2}{|c|}{$200 \mathrm{~g}$ protein $/ \mathrm{kg}$} & \multicolumn{2}{|c|}{$30 \mathrm{~g}$ protein $/ \mathrm{kg}$} \\
\hline & Mean & SD & Mean & SD \\
\hline Saline & $<0.05$ & & $0 \cdot 11$ & $0 \cdot 02$ \\
\hline Turpentine & 4.85 & 0.55 & $1 \cdot 28 * * *$ & $0 \cdot 28$ \\
\hline Pair-fed & $<0.05$ & & 0.10 & 0.01 \\
\hline
\end{tabular}

*** Mean value was significantly different from that for the corresponding $200 \mathrm{~g} / \mathrm{kg}$ group: $P<0 \cdot 001$.

$\dagger$ For details of diets and procedures, see pp. 124-125.

significant changes in their protein content but not their mass (or vice versa). For example, turpentine injection in normally nourished animals provided a significant increase in the protein content of the heart (compared with pair-fed controls), but not in its mass.

Finally, the present study has not only confirmed that protein deficiency attenuates the acute-phase-protein response (Jennings \& Elia, 1991, 1992; Jennings et al. 1992a), but it has also demonstrated that protein deficiency attenuates two other responses to injury. One of these is the anorectic effect of injury, which was essentially non-existent in the proteindeficient animals during the first $48 \mathrm{~h}$. The second is the attenuation in the protein 
distribution induced by turpentine. The cause of these attenuations is not clear, but theoretically it may be due to reduced local reaction to turpentine administration, which was not observed in a previous study (Jennings et al. 1992b), or to either altered hormonal and/or cytokine responses, or altered tissue responsiveness to these signals.

\section{REFERENCES}

Addis, T., Poo, L. J. \& Lew, W. (1936). Quantities of protein lost by the various organs and tissues of the body during a fast. Journal of Biological Chemistry 115, 111-116.

Ardawi, S. M. (1992). Hepatic glutamine metabolism in the septic rat. Clinical Science 82, 709.

Ash, S. A. \& Griffin, G. E. (1989). Effect of parenteral nutrition on protein turnover in endotoxaemic rats. Clinical Science 76, 659-666.

Bell, R. \& Hoffman-Goetz, L. (1983). Effect of protein deficiency on endogenous pyrogen-mediated acute phase protein responses. Canadian Journal of Physiology and Pharmacology 61, 376-380.

Besler, H. T. \& Grimble, R. F. (1995). Comparison of the modulatory influence of maize and olive oils and butter on metabolic responses to endotoxin in rats. Clinical Science 88, 59-66.

Carter, E. A., Jung, W., Ehrlich, H. P. \& Quellette, A. (1988). Thermal trauma and gastrointestinal function. III. Effect of hot and cold burn trauma on small intestinal weight and mucosal mass of mice. Journal of Burn Care and Rehabilitation 9, 351-353.

Drabik, M. D., Schnure, F. C., Tong Mok, K., Maldawer, L. L., Dinanello, C. A., Blackburn, G. L. \& Bistrian, B. R. (1987). Effect of protein depletion and short-term parenteral re-feeding on the host response to interleukin-1 administration. Journal of Laboratory and Clinical Medicine 109, 509-516.

Elia, M. (1991). Organ and tissue contribution to metabolic rate. In Energy Metabolism: Tissue Determinants and Cellular Corollaries, pp. 61-80 [J. M. Kinney and H. N. Tucker, editors]. New York: Raven Press.

Ferrari-Baliviera, E., Mealey, K., Smith, R. J. \& Wilmore, D. W. (1989). Tumour necrosis factor induces adult respiratory distress syndrome in rats. Archives of Surgery 124, 1400-1405.

Fong, Y., Minei, J. P., Marano, M. A., Moldawer, L. L., Wei, H., Shires, G. T. \& Lowry, S. F. (1991). Skeletal muscle amino acid and myofibrillar protein mRNA response to thermal injury and infection. American Journal of Physiology 261, R536.

Garlick, P. J., Millward, D. J., James, W. P. T. \& Waterlow, J. C. (1975). The effect of protein deprivation and starvation on the rate of protein synthesis in tissues of the rat. Biochimica et Biophysica Acta 414, 71-84.

Grimble, R. F., Jackson, A. A., Persaud, C., Wride, M. J., Delers, F. \& Engler, R. (1992). Cysteine and glycine supplementation modulate the metabolic response to tumor necrosis factor $\alpha$ in rats fed a low protein diet. Journal of Nutrition 122, 2066-2073.

Hunter, E. A. \& Grimble, R. F. (1994). Cysteine and methionine supplementation modulate the effects of tumour necrosis factor $\alpha$ on protein synthesis glutathione and zinc concentration of liver and lung in rats fed a low protein diet. Journal of Nutrition 124, 2319-2328.

Jennings, G., Bourgeois, C. \& Elia, M. (1992a). The magnitude of the acute phase protein response is attenuated by protein deficiency in rats. Journal of Nutrition 122, 1325-1333.

Jennings, G., Cruickshank, A. M., Shenkin, A., Wight, D. G. \& Elia, M. (1992b). Effect of aseptic abscesses in protein deficient rats on the relationship between interleukin- 6 and the acute phase protein, $\alpha_{2}$-macroglobulin. Clinical Science 83, 731-735.

Jennings, G. \& Elia, M. (1991). Independent effects of protein and energy deficiency on acute-phase protein response in rats. Nutrition $7,430-434$.

Jennings, G. \& Elia, M. (1992). The acute-phase response to turpentine-induced abscesses in malnourished rats at different environmental temperatures. Metabolism: Clinical and Experimental 41, 141-147.

Jennings, G. \& Elia, M. (1994). Effect of dietary restriction on the response of $\alpha_{2}$-macroglobulin during an acute phase response. Journal of Parenteral and Enteral Nutrition 18, 510-515.

Jennings, G., Lunn, P. G., Northrop-Clewes, C. A. \& Elia, M. (1991). The effect of endotoxin and turpentine administration on intestinal permeability in the rat. Clinical Nutrition 10, 43-46.

Jepson, M. M., Bates, P. C., Broadbent, P., Pell, J. M. \& Millwood, D. J. (1988). Relationship between glutamine concentration and protein synthesis in rat skeletal muscle. American Journal of Physiology 255, E166-E172.

Jones, W. G., Minei, J. P., Barker, A. F., Rayburn, J. L., Fahey, T., Shires, G. T. \& Shires, G. T. (1990). Bacterial translocation and intestinal atrophy after thermal injury and burn wounds. Annals of Surgery 211, 399-404.

Lunn, P. G., Whitehead, R. G. \& Baker, B. A. (1976). The relative effects of a low-protein-high-carbohydrate diet on the free amino acid composition of liver and muscle. British Journal of Nutrition 36, 219-230.

Pedersen, P., Saljo, A. \& Hasselgren, P.-O. (1987). Protein and energy metabolism in liver tissue following intravenous infusion of live E-coli bacteria in rats. Circulatory Shock 21, 59-64.

Stein, T. P., Leskiw, M. J., Wallace, H. W. \& Oram-Smith, J. C. (1977). Changes in protein synthesis after trauma: importance of nutrition. American Journal of Physiology 233, E348-E355.

Thelfall, C. J., Little, R. A. \& Frayn, K. N. (1979). The post-scald metabolic response in the growing rat: evidence for a transient phase of muscle protein breakdown. Burns 7, 25-32. 
Tran, T. A., Macry, J., Medy, F., Kahn, J. M. \& Cezard, J. P. (1991). The effect of acute phase inflammation on small intestine morphology and function in the rat. Clinical Nutrition 10, Suppl., 42.

Wusteman, M. \& Elia, M. (1990). Protein metabolism after 'injury' with turpentine: a rat model of clinical trauma. American Journal of Physiology 259, E763-E769.

Wusteman, M. \& Elia, M. (1991). The effect of glutamine infusions on glutamine concentration and protein synthetic rate in rat muscle. Journal of Parenteral and Enteral Nutrition 15, 521-525.

Wusteman, M., Hayes, A., Stirling, D. \& Elia, M. (1994). Changes in protein distribution in the rat during prolonged 'systemic injury'. Journal of Surgical Research 56, 331-337.

Wusteman, M., Tate, H.\& Elia, M. (1995a). The use of a constant infusion of phenylalanine to measure the effects of glutamine infusions on muscle protein synthesis in rats treated with turpentine. Nutrition 11, 27-31.

Wusteman, M., Tate, H., Weaver, L., Austin, S., Neale, G. \& Elia, M. (1995b). The effect of enteral glutamine deprivation and supplementation on the rat small intestinal mucosa during a systemic injury response. Journal of Parenteral and Enteral Nutrition 19, 22-27.

Wusteman, M., Wight, D. G. D. \& Elia, M. (1990). Protein metabolism after injury with turpentine: a rat model for clinical trauma. American Journal of Physiology 259, E763-E769. 